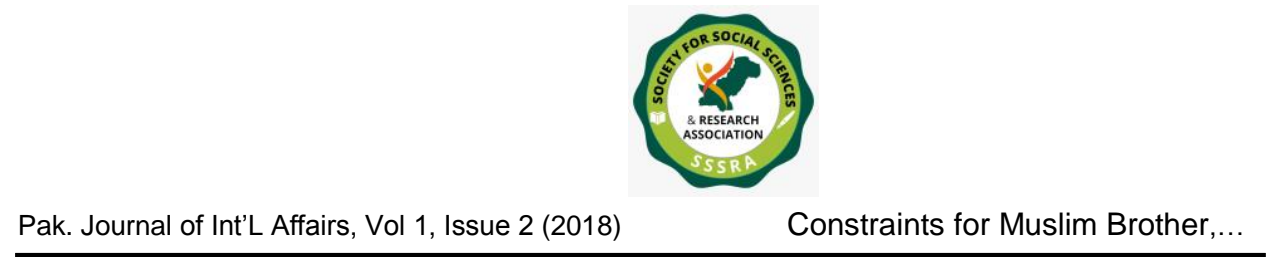

\title{
CONSTRAINTS FOR MUSLIM BROTHERHOOD IN THE POLITICS OF EGYPT
}

\author{
* Muhammad Nawaz Awan, Research Scholar, Department. of International Relations, \\ Federal Urdu University, Karachi- Pakistan \\ **Dr. Mamnoon Ahmed Khan , Incharge, Department. of International Relations, \\ Federal Urdu University, Karachi- Pakistan (mamnoonak@gmail.com)
}

\begin{abstract}
This Political party was established in Egypt in 1920. His founder was Sheikh-al-hasan Al banna and he was from the village of Alexandria. He started this group in 1923 but it is properly established in 1929. His motivation was to reassure and implement the basic beliefs of Islam, but later it took political form. This movement was very popular in Egypt and its branches will also be established in other Arab countries. On the end of the Second World War, its members had a population of 20 million. It was a democratically party dictatorship and wanted to end the kingdom, abstain from militancy, it has many services for Egypt's people. In addition, he used to present in welfare works, they established thousands of schools in Egypt in which general public used to get education. The organization became very popular because it was consisting of educated people, the party of Palestine, Hamas was also the part of Muslim Brotherhood. The Muslim Brotherhood worked hard to end the kingdom, but every time the party was pressed and was not given any success in any way, because this party only wants the democratic government. In 1952, Muslim Brotherhood was a pro-Egyptian military revolution, but it also opposed General Najeeb and General Nasir's foreign policy. In 1954, some of the party workers was unsuccessful to assassinate general Nasser, after which it was considered as a law-enforcement law and their property was confiscated. Then the leader of the group Sheikh Hassan Aldebi changed his president's position from Damascus to Cairo. This group raised a loud voice against Arab nationalism and slammed the Islamic Brotherhood. In the past, many members of the party were closed in prisons and executed martyred like Syed Qutb. After this ban, the group remained and spread across the entire Arab territories. The Muslim League has close ties with Pakistan. In my article I am giving light on the role of the Muslim Brotherhood for Egypt.
\end{abstract}


KEYWORDS: Egypt, Muslim, Hasan Al Banna, Muslim Brotherhood, Military.

\section{INTRODUCTION}

From where the work of state welfare organizations ends, social services are started. As Muslim Brotherhood do the work of completing state duties from their respective states, the state operations have done that the numbers will go underground. After which their main position will end and they will take revolutionary direction. So Salafi jihadist group is also giving the justification of politics by doing similar kind of welfare services across the region. Mohammad Alam established the Islamic Medical Association (IMA) whose aim was to provide high-standard treatment at low cost. The organization is the biggest and the oldest community of the Muslim Brotherhood. (Wasimuddin, 2007) Until the military uprising IMA was running 22 hospitals and 7 research centers, one optical disease center and a medical center of disabilities, center for curing infertility and mobile implementers. After the military coup, security forces went to every hospital of the IMA and check that they were registered or not and their documents were completed or not. The IMA was forced to separate the prominent leader of the Muslim Brotherhood from its administrative board in which Freedom and justice party members included the names of Parliament Halmi al-Jazeer and Jamal Hashmat. The false members of Muslim Brotherhood which were related with IMA and city central charity hospital director went to abroad and some of them were arrested. In December 2013, the IMA was included in the list of social organizations affiliated with the Muslim Brotherhood. (Shahabuddin, \& Rauf, 2014)

IMA instantly polish at the first page of daily newspaper "Ala Haram" that It should be allowed to work for two million ill people and millions of patients and those who are required to have immense dialects are already in need and those who are unable to afford their treatment, is needed to come to the hospital. After a few months later, the IMA Director Hospital Administration said that three new hospitals are going to be formed very soon. However, in the early 2015, the government immediately took control on the IMA and seized it and assets worth 360 million Egyptian pounds.

\section{ROLE OF HASAN AL BANNA}


Hassan Al-Banna was conceived in 1906 in Mahmoudia, close Alexandria, Egypt. He moved on from Dar Al-Uloum school in Cairo and worked in the field of instruction in a few towns, calling individuals to take after the Qur'an and the Sunnah. He could manual for the Path of Allah a huge number of individuals of all classes of his general public.

Imam Al-Banna remained in Ismailiah, Egypt for quite a while where he built up the primary community for Al-Ikhwan with a gathering of his siblings. He began making Da'wah openly through addresses and distributions and visits to towns and towns. His action was not just kept to men, he likewise settled in Ismailiah "The Muslims' Mothers Institute" for instructing young ladies as indicated by Islamic lessons. (Anani, 2007)

After some time, he was exchanged to Cairo to which he exchanged his home office. Cairo turned into the focal point of Da'wah and in a brief span the quantity of Brotherhood came to about a half million. This gigantic advance began to concern the British and their adherents, the Egyptian legislators. They attempted to prevent Imam AlBanna from legislative issues yet he demanded his position. He built up a day by day daily paper in Cairo by the name "Al-Ikhwan Al-Muslimoon" (Muslim Brotherhood) which empowered him to address a substantially bigger area of people in general than with addresses.

At the point when the awfulness of Palestine occurred, the Brotherhood troops were among the most dynamic powers and could reach to the entryways of Tel Aviv and nearly vanquished it on the off chance that it had not been for the conspiracy by the Arab rulers around then. Besides, King Farouq of Egypt detained countless. At long last, a plot was made by the British and actualized by their hirelings to kill Imam AlBanna. He was shot before the "Muslim Youth Association" working in March 1949. After he was conveyed to the healing center, he was left on the floor seeping with nobody attempting to spare him. Two hours after he was shot, he passed away, at just 43 years old. (Shahabi, 1993)

\section{ESTABLISHMENT OF MUSLIM BROTHERHOOB}

Cities have more moral management than rural areas, this was the case of Cairo. When Hasan al-Banna came from his town to Cairo, so on his sensitive nature, the non-Islamic region of the city had so much 
influence. He saw that Egypt is being part of Europe and is invited to move back in the era of froon. They also realized that although scholars are against non-Islamic ideology, but there is no way to eliminate their evils. That's why in 1928 in the city Ismailia where he became a teacher after receiving a certificate, lead the foundation of the organization of the Muslim Brotherhood. In 1933, the President office of the Muslim Brotherhood moved from Ismailia to Cairo. (Ahmed, 1990)

\section{SOCIAL SERVICES OF MUSLIM BROTHERHOOB}

\section{MOVEMENT LIFE:}

Hasan al-Banna announced that the message of Islam is universal and it is a complete system of life. Through the Muslim Brotherhood organization, he started to give his idea the shape of reality. Muslim Brotherhood branches were established in all dimensions off Egypt, they united the students and the workers and a separate division of the Muslim Brotherhood was set up for organization of women. The Muslim Brotherhood also established in support and took part in the work for the public. He set up a system training in which Muslim Brotherhood workers can become the best kind of Muslims. (Montanye, 2005).

\section{DEMAND FOR IMPLEMENTATION OF ISLAMIC LAW}

Hasan al-Abana ask the implementation of Islamic laws for the establishment of the Islamic government. He said that for fifty years, nonIslamic laws are being tried in Egypt. And they are fierce, so Islamic law should be tested, he emphasized that the present Rules and Regulation of Egypt is not just the book and tradition of the law, but the laws and regulations of the European countries, which is confused in Islam Hasan al-Abana also spread the spirit of jihad in the Egyptians and wrote a permanent report on this subject, and told that Imam Badruddin Aini Sharah Bukhari, used to worship Jihad one year, and used to perform Hajj for one year. (Turner, 2010).

\section{MUSLIM BROTHER HOOD AND MEDIA:}

Brotherhood also focused on newspapers and magazines. After the death of Rasheed Raza in 1935, Hassan al-Banna issued his magazine Al-Manar, and Muslim Brotherhood also released a daily, weekly and monthly report. The daily newspaper Muslim Brotherhood was included in 
the people of Egypt's first row. Through these publications and small books, the Muslim Brotherhood promoted his influence and goals and told how Islam guide the world in various fields of life. (Zhongdan, \& Michael 1993)

\section{GUIDANCE OF ISLAMIC WORLD:}

Professor Hasan-al Banna was the teacher in University of Azhar. They believed that Turkey has turned away from the guidance of the Islamic world. And now it is believed to be Egypt that he should lead the Islamic world into your program to completely exclude foreigners from Egypt and establish an Islamic government in Egypt.

He said that;

"It is maybe now the biggest and most dangerous illness of our society that they do not feel of his disease and does not worry about slavery"

Near him dangerous illness is have distance from religion and presence of foreign country people in Egypt, and Capture of Americans on Muslim countries. Hussain al-Anwar was keen that all the Islamic world were present on the basis of one unit and the Muslim Brotherhood lead this party. (Shahabuddin, \& Rauf, 2014)

\section{LIGHTING UP WITH ISLAMIC TEACHING}

The founder of the party professor Hasan Banna said that Allah does not change the condition of a nation unless he has changed himself. Hussain created feeling of patriotism in the hearts of the people through the Muslim Brotherhood. Hussein awaken the spirit of a homeland in the hearts of the people of Egypt. (Qurzawi. 2004)

\section{PATRIOTISM}

Hassan al-Banna created feeling of patriotism in the hearts of Egyptians. The aim of the Muslim Brotherhood was to exit foreigners completely from Egypt and the formation of the Islamic government.

POLITICAL ORGANISATION 
Hassan al-Banna was founded Muslim Brotherhood on the basis of the basic beliefs and implementation of Islam. Later this party was adopted as a political form. This movement became popular in Egypt; the branch of the branch will be established in other Arab countries. At the end of the Second World War its worker quantity increases up to 20 lacs. (Antar, 2006)

In the starting of Second World War the basis of Muslim Brotherhood was became strong in other Arab countries. But Egypt was the only strong unit of Muslim Brotherhood. After Second World War, Muslim Brotherhood took part in welfare activates. In 1948, they participated in the fight of Palestine against Britain. And workers of Muslim Brotherhood fought bravely in comparison of government soldiers. Muslim Brotherhood changed from religious party to political party and leave Egypt and shifted to Arab. Sheikh Hassan al-Banna felt intensely that the party should be used for political purposes, so that the name of the party was called for the invitation. Announcing the Monetary Declaration, Hassan al-Banna said:

"It is our belief that Islam is the belief of both the teachings of Islam and its worldly life. There is also worship, and there is also a country like this, Islam is also a heart, and there is also a government"

Explaining Sheikh, said that our goal is to establish a government according to the Quran's consensus. (Qurzawi. 2004)

\section{ECONOMIC CONDITION}

Hussein al-Banna also focused on the economic situation of Egyptian people. He established the welfare agencies in Egypt to improve the situation of the Egyptian people. He provided health and education facilities to the people and creates sources for the employment of peoples. There was huge land in the country, the investor had occupied the national resources

\section{WELFARE SERVICES}


Hassan Banna was struggling to establish the welfare organizations. In which many schools were established and colleges also made in which normal public got education. Apart from this, services for disabled and poor people are served.

\section{GUIDE TO ARAB NATION}

Hassan Banna wanted after turkey, Egypt was a country in which Arabs should be guided. It had work that his party came out of Egypt and spread throughout Egypt. Today millions of workers of this great work are being fulfilled throughout the Arabs. In the Arab country, everywhere in the Arab world belongs to it. The biggest act of Hassan al-Banna was to create a great idea throughout Egypt. Hassan al-Banna created the whole Arab and especially Egyptian people thinking that he is a state. They cannot live the British slaves, in a state, they have thought of peace and thought in all the Egyptians. In 1928, Prof. Banna for Egyptian preparing for the leadership of Muslims of religious Islam lead the foundation of Muslim Brotherhood. (Qurzawi. 2004)

\section{THE SIGN OF MUSLIM BROTHERHOOD:}

This group was established in Egypt in 1920. His founder was Sheikh-ul-Hasan Al-Banna and he was from the village of Alexandria. $\mathrm{He}$ started this group in 1923 but it is properly established in 1929. His motivation was to reassure and implement the basic beliefs of Islam, but later it took political form. This movement was very popular in Egypt and its branches will also be established in other Arab countries. On the end of the Second World War, its members had a population of 20 million.

It was a democratically party dictatorship and wanted to end the kingdom, abstain from militancy, it has many services for Egypt's people. In addition, he used to present in welfare works, they established thousands of schools in Egypt in which general public used to get education. The organization became very popular because it was consisting of educated people, the party of Palestine, Hamas was also the part of Muslim Brotherhood. The Muslim Brotherhood worked hard to end the kingdom, but every time the party was pressed and was not given any success in any way, because this party only wants the democratic government. (Korotayev, 2011). 
In 1952, Muslim Brotherhood was a pro-Egyptian military revolution, but it also opposed General Najeeb and General Nasir's foreign policy. In 1954, some of the party workers was unsuccessful to assassinate general Nasser, after which it was considered as a law-enforcement law and their property was confiscated. Then the leader of the group Sheikh Hassan Aldebi changed his president's position from Damascus to Cairo. This group raised a loud voice against Arab nationalism and slammed the Islamic Brotherhood. In the past, many members of the party were closed in prisons and executed martyred like Syed Qutb. After this ban, the group remained and spread across the entire Arab territories. The Muslim League has close ties with Pakistan. Today, Islamic leaders around the world belong with Brotherhood in which Al-Qaeda leader Amin al-Zawahiri, Hamas leader Sheikh Ahmed Yassin and Dr. Abdul Aziz are included. (Wasimuddin, 2007)

\section{THE INVITATION OF MUSLIM BROTHERHOOD FOR ISLAMIC VALUES:}

In the starting of second world war the basis of Muslim Brotherhood was became strong in other Arab countries. But Egypt was the only strong unit of Muslim Brotherhood. After second world war, Muslim Brotherhood took part in welfare activates. In 1948, they participated in the fight of Palestine against Britain. And workers of Muslim Brotherhood fought bravely in comparison of government soldiers. (Geddes, 1999).

In addition, the British Muslims announced the independence of Egypt, the Muslim world immediately demanded to fulfill it. This led to a huge increase in the popularity of Muslim Brotherhood, and the number of members of the Muslim Brotherhood within two years reached five million. The numbers of sympathizers were doubled. On the one hand, Shah Farooq I felt threatened, Britain on the other hand began to emphasize Egypt's to band Muslim Brotherhood. (Mitchell, 1969).

\section{BAN ON THE MUSLIM BROTHERHOOD}

On the one hand, Shah Farooq I felt threatened, Britain on the other hand began to emphasize Egypt's to band Muslim Brotherhood. So, December 9, 1948, the government ruled against the Muslim Brotherhood that many thousands of Muslim workers were arrested. 
The second-arm in the Muslim Brotherhood social services network is private school's sectors to handle the control of the IMA at September 2013 the judicial proceedings in which a Muslim was declared terrorist organization, the Muslim Brotherhood schools were taken into state control based on the court's verdicts of court. Earlier schools were asked to continue the management of a committee of Ministry of Education, afterwards, these schools were handed over to the June 30 School Committee. The state is accused that the Muslim Brotherhood is working to accuse the school against the army and police, for instance, the state is accused that the Muslim Brotherhood is working to accuse the school against the army and police, for instance, a student of Barbie will be identified. As today's military and police talk about paying freedom. (Iyengar, 2005).

In some cases, the security forces reached the school directly and arrested people from there on the charge that they were attacking the state. The people associated with the schools rejected these allegations indefinite, but they also called out this investigation meaning less. The government took control of IMA in a calm manner, but the students of the schools worked harder. An obstacle of bureaucracy is that the government does not directly contact the schools, but whatever committee is to say, the committee combines its government's highest level. At sometimes, the court has accused the officials of education because of the fact that both did the matter directly from the schools. In the meantime, the prime minister had less ability to execute. So, the effect of the school's board of directors dismissed the demand for dissolution of the board and continued to work as if nothing changed. (Susser, 2012).

The government's point of view is another problem that a court verdict of September 2013, which applies to the legal property of the Muslim Brotherhood only to corporate entities. While the matter of schools is that many schools are in individual property, and include those prominent Muslim Brotherhood leaders.

The government started a new effort to control the Muslim Brotherhood school in January 2015 as the Board of Directors was appointed in all schools as a new law. The ministry has specifically announced that it will be given by the security services to the students before the participants, that the students will not be able to wear hijab on the face. Similarly, the hijab will not be demanded from the students. In February 2015, the Ministry claimed that an $85 \%$ of the Muslim 
Brotherhood school are in their grip. Now the authority of the Egyptian authorities has got the risk of government systems to absorb the group's imagination. Egyptian commands will have authority to consume the group considered to be a threat to the government system. So, the legal license to confiscate the Muslim Brotherhood schools were allowed to seize the assets of the Muslim Brotherhood front in March.

New government started the July 3, 2013 coup after the military uprising, with the efforts of the government to start the Afghan government's national services, the Government's move has threatened not only millions of people. Those peoples who terminate these words for their daily needs, send them to Muslim, who have emphasized the supply of social services in their struggle over the centuries A practical result of the rearing campaign is that innovation is used as a high-efficiency tool. Salafi jihadist groups have been promoting the promotion of the legal code of ethical behavior. In which they offer their welfare social services while challenging the state's justification and violence is also traditionally. In the night and evening, the present achievements of the Islamic State's success and the same nature of other movements in the region itself. There are similar example inner Egypt. (Iyengar, 2005).

This group came out of Egypt from the inside. Egypt's continuous economic and social problems show that there is a chance to flourish such movements. They are crushing the Egyptian government's welfare work, but the main demands of the citizens are not getting rid of them to provide reasonable accessible facilities. So, the future of Islamic social services will continue to be debated. In other words, if Egypt walks on its own way, then a small Muslim extremist group or jihadist group will not work in plotting to dominate the ruling regime. Rather, it will be a wide range of insurgent attacks of Egyptian people who change such leaders for decades, ask for more than citizens and say least to convince them. President has supported the Muslim Brotherhood for a period. The Muslim Brotherhood and his other views have seen the Qatari government as a force to fulfill its institutions. That's why they had openly supported the Muslim Brotherhood and all groups for ten years, and they also worked as a media platform. (Aouragh,\& Alexander, 2011) The United Arab Emirates, Kuwait and Bahrain, have always seen the support of the Muslims by Qatar, in doubt, in a phenomenon that the Qatari government, on the other hand, has begun to change the future of the Arab world to form the Muslim system of political law on this kind of political system which was not right. In January 2011, the wave of public awareness, Muslim 
Brotherhood won the election in Tunisia and Egypt. It could not win success in Tunisia for the second time and the government overturned in Egypt. (Lovenheim, 2011).

The former Egyptian President, who belonged to the Muslim Brotherhood was de-throne and renowned by government. The support of groups from the Muslim Brotherhood in Syria and Yemen also grew up. A group from Palestine griped weapons in 1990 who was in ideological support of Muslim Brotherhood and establish their government on Ghazi strip. Turkey did development under the banner of Justice and Development Party in this period. Rajab Tayyip Erdogan founded a new Turkey. The military operation in the Turkish state and state affairs was unusually reduced and there is a development that looks like a model and a big brother in the whole region. It has evolved in most of the world's development. That Styles can be flexible and can be reached to better location. The journey that started early in the Arab world with the wave of awareness in the Arab world has not been seen yet to be eliminated. (Mandel, 2003).

The government of the Muslim Brotherhood has been demolished and after that it has also declined in support. The models of the Muslim Brotherhood are being presented in politics with the power of the model, the support of external forces is decreasing.

\section{POLITICAL PROBLEMS FOR MUSLIM BROTHERHOOD}

Why the difficulties increases are for the Muslim Brotherhoods, in this matter blame should be given to the Muslim Brotherhood? When the movement of the colonial forces to move from the Arab world moved, many people from Muslim Brotherhood made models for themselves. The central leadership of the Muslim Brotherhood and ideology were largely moderate. He resolved almost all of the problems of life as Islam. Any major change in view of consolation is to change the system from inside, the phase of the system and avoid taking a weapon possible. Muslim Brotherhood has achieved success in reaching in parliament with a wave of awareness at the Arabic world but in some cases unable to figure out the truth. People of Muslim Brotherhood in Tunisia and Egypt have been successful, so people have successfully supported the poor candidate of the Muslim. In the two countries, the Muslim Brotherhood had a great opportunity to make the government. Although the Muslim Brotherhood could do a lot, understanding matters better and correcting them was not a 
point for the Muslim Brotherhood, but the leaders fail to understand victory. (Iyengar, 2005). The Muslim Brotherhood succeeded in Tunisia and Egypt because the other political parties were weakened and people were influenced by the past of Muslim Brotherhood. It was inevitable that the new idea was adopted that something new to the front came smoothly to improve the matter. The moderate elements behind the leadership of the Muslim Brotherhood were behind. Revolutionary elements wanted everything to happen in nights and they would not be able to move quickly and they would be dealt with in such a way. There was a lot of improvement in Iraq and Syria on the majority of Sunnis. In this situation it has been shown that weapons will be taken to show even in Egypt and Tunis. The Muslim Brotherhood and supporting groups attempted to adopt a revolutionary style, they failed very badly. After the Syrian civil war began,

Muslim Brotherhood tried to appear as a most important political party of parliament, but now its influence is limited. The Muslim Brotherhood is also strange. most of the forces of the West found more favorable attitude toward the Muslim Brotherhood than the revolutions, but on the other hand, most of the Arab world believe this organization as a home that they will look at it alternatively. The class that has been ruled in Egypt for four centuries considered Muslim Brotherhood as the greatest threat for them. After removing President Mohammed Morsi, thousands of young people from the Muslim Brotherhood were killed. Thousands are now prison. Many people are very disturbed in the name of investigation, the trial is being carried out against the entire leadership of the Muslim Brotherhood in Egypt and there has been an impact on Hamas by all this. Gulf states focused on reducing the risk of danger from Muslim Brotherhood. He also started monitoring the supporter of the Muslim Brotherhood. (Hamdy, \& Ehab 2012).

The effort is being in process to limit the influence of the Muslim Brotherhood in the whole region of the Gulf, after Egypt, Saudi Arabia and the United Arab Emirates have now declared Muslim Brotherhood some terrorism organizations. After the overthrow of the Muslim Brotherhood government in Egypt, the Saudi Arab states gave full support and assistance to Egypt's military government to reduce the impact of Muslim Brotherhood. On the other hand, pressure on Qatar and other states has also been encouraged to deny supporting Muslim Brotherhood. This policy was largely supported by the Gulf States of the Muslim Brotherhood opposition groups in Syria and Libya. It is also an effective 
way to weaken Muslim Brotherhood. The results were found for the measures of limiting the impact of the Muslim Brotherhood, and Qatar and many other countries have felt insecurity in the field of self-determination. Yemeni and other countries strengthen the influence of the Muslim Brotherhood, the Shiite groups in Yemen have stepped up against the support of the Muslim Brotherhood. (Lakoff, \& Turner, 1989).

\section{CONCLUSION}

This party was started in 1928 by the former citizen of Al-Zahar Professor Banna. His main motive was to aware his fellow citizens about the right teaching of Islam. The purpose of the attempt of the Muslim Brotherhood is to mean that Muslims should be enlightened with the correct teachings of Islam that they color their lives with the paint of Islam. The purpose of this group is to call people towards the real and practical greetings of Islam, because the thought of the Muslim brotherhood is in the same way as Islam. After this, gradually spreading things in many of our people and in this way, the thought shaped a grouped. Due to unusual decline in support, the Muslim Brotherhood has been limited to the Opinion. Many of the activists and leaders of Muslim Brotherhood have taken shelter in Turkey. It seems that the Egyptian government is no longer able to understand that the how to eliminate Muslim Brotherhood. Egypt was welcomed by the government for some time, after the overthrow of the Muslim Brotherhood. And it is also being understood that if the Muslim Brotherhoods bleed from badness, it can also be included in government making. But the change in the strategy of Egyptian media should change if the government shows any kind of softness, it will be considered to be a knee-kneeled in front of Muslim Brotherhood. In recent days the government has indicated that the Muslim Brotherhoods can be banned, the government has said that if every Muslim is a political branch, if the party is attributed to political branches will be canceled. These Egyptians may be grateful that they believe in the Muslim Brotherhood, but with custom Muslim Brotherhood will go to the former underground. Meanwhile, the government is taking full emphasis on the Muslim Brotherhoods to be presented in the form of terrorist organization, and they have given many videos in the media about this topic. Like the previous military governments, the recent government of the present government wants to present the Muslim brotherhood by putting a book of sacrifice to cover their works, when it is asked to be strengthened and questioned, it is a great danger. 


\section{REFERENCES}

Ahmed, I., (1990) Akhwan ul Muslimoon, Meezan Publishers, Lahore, p273.

Anani, K. al. (2007) The Muslim Brotherhood in Egypt: The Senility of Time's Struggle?. Cairo: El Shorouk International Publisher.

Antar, N. (2006) "The Muslim Brotherhood's Success in the Legislative Elections in Egypt 2005: Reasons and Implications." Euromesco Paper 51, p- 1-33.

Aouragh, M, and Alexander, A., (2011) "The Egyptian Experience: Sense and Nonsense of the Internet Revolution." International Journal of Communication 5, pp -1344-1355.

Geddes, B. (1999). "What Do We Know About Democratization After Twenty Years?” Annual Review of Political Science. Vol. 2, p. 115-144.

Hamdy, N. \& Ehab G. (2012). "Framing The Egyptian Uprising In Arabic Language Newspapers And Social Media." Journal of Communications. 62(2), p. 195-211

Iyengar, S. (2005). "Speaking Of Values: The Framing Of American Politics." The Form. 3(3), Article 7. Retrieved January 18, 2013 from: http://pcl.stanford.edu/common/docs/research/iyengar/2005/speaking.pdf

Korotayev, A. \& et al. (2011). A Trap At The Escape From The Trap?" Cliodynamics: The Journal of Theoretical and Mathematical History. Retrieved October 16, 2012 from: http://escholarship.org/uc/item/79t737gt

Lakoff, G. \& Turner, M, (1989). "More Than Cool Reason: A Field Guide to Poetic Metaphor." Chicago: University of Chicago Press.

Lovenheim, S. (2011). "What Do Egypt's Protestors Want?" The Washington Post. Retrieved October 18, 2012 from: http://voices.washingtonpost.com/postpartisan/2011/02/what_do_egypts_p rotesters_want.html 
Mandel, E. (2003). "What Is A Revolution." International Viewpoint. Retrieved October 2, 2012 from:

http://www.internationalviewpoint.org/spip.php?article159

Montanye, J. (2005). "Rhetoric and Economic Policy." The Independent Review. 9(3), p325-338.

Mitchell, R. P. (1969). "The Society of the Muslim Brothers.” New York, NY: Oxford University Press.

Qurzawi. A. Y., (2004) 70 Years of Muslim Brotherhood, Maktiba Misbah, Lahore, p-117.

Shahabi, F. A., (1993) Muslim World, Islamic Research Academy, Lahore p-358.

Shahabuddin, S. \& Rauf, B.M., (2014) Educational Services of Muslim Brotherhood in Egypt, Maárif Research Journal Vol. 6 Issue, Karachi Pakistan, pp-133-143.

Susser, A., (2012). "The 'Arab Spring': The Origins Of A Misnomer." Foreign Policy Research Institute. Retrieved February 15, 2013 from: https://www.fpri.org/articles/2012/04/arab-spring-origins-misnomer

Turner, B., (2010). "Revisiting Weber And Islam.” The British Journal Of Sociology. Vol. 61, p - 161-166

Wasimuddin, S., (2007) Historical Survey of Akhwan-UL -Muslimoon as a Political Party of Egypt, New Horizons, Vol. 1, Issue, pp -51-60,

Zhongdan, P. and Michael K., (1993). "Framing Analysis: An Approach to News Discourse.” Political Communication. 10(1), p -55-75 